\title{
Reactive improvement of environmental policies: lessons from the Mariana and Brumadinho disasters
}

\author{
Aperfeiçoamentos reativos de políticas ambientais: lições \\ dos desastres de Mariana e Brumadinho
}

\author{
Michelle Cristina dos Reis Braga ${ }^{1}$ \\ Alberto de Freitas Castro Fonseca ${ }^{2}$
}

${ }^{1}$ Master in Environmental Engineering, Researcher, Programa de Pós-Graduação em Engenharia Ambiental, Universidade Federal de Ouro Preto, Ouro Preto, Brazil E-mail: michelle.braga@aluno.ufop.edu.br

${ }^{2}$ PhD in Sustainable Development, Researcher, Programa de Pós-Graduação em Engenharia Ambiental, Universidade Federal de Ouro Preto, Ouro Preto, Brazil E-mail: alberto@ufop.edu.br

doi:10.18472/SustDeb.v12n1.2021.39412

Received: 19/08/2021

Accepted: 25/11/2021

ARTICLE - VARIA

\begin{abstract}
The State is not always able to proactively improve environmental policies. Eventually, policy improvements are a result of disasters that expose pre-existing problems. This situation is reflected in the state of Minas Gerais (Brazil), where, after the failures of the Fundão and B1 tailings dam, in Mariana and Brumadinho, several problems in dam safety and emergency policies were exposed. This study had a twofold objective: 1) to identify the mechanisms used by the government of Minas Gerais to improve environmental policies, and 2) to understand how the Mariana and Brumadinho's disasters affected dam safety and emergency policies. Based on semi-structured interviews and regulatory analysis, the study revealed that the state government of Minas Gerais has been predominantly reactive in controlling environmental policies. Additionally, it was observed that the disasters catalysed a learning process that culminated in potentially better dam safety policies.
\end{abstract}

Keywords: Environmental Policy Assessment. Environmental Disasters. Tailings Dams. Regulatory Learning.

\section{RESUMO}

O Estado nem sempre é capaz de aperfeiçoar políticas ambientais de maneira proativa. Eventualmente, melhorias políticas se dão em reação a desastres, que expõem, contundentemente, problemas preexistentes. Essa situação está refletida no estado de Minas Gerais (Brasil) onde, após as rupturas das barragens de rejeito de Fundão, em Mariana, e B1, em Brumadinho, ficaram expostas lacunas nas políticas de segurança e emergência de barragens. Este estudo teve dois objetivos: 1) identificar os mecanismos utilizados pelo governo de Minas Gerais para aperfeiçoar políticas ambientais; e 2) 
entender como os desastres de Mariana e Brumadinho afetaram as políticas de segurança e emergência de barragens. Baseado em entrevistas semiestruturadas e análises regulatórias, o estudo revelou que o Estado tem sido predominantemente reativo no controle de políticas ambientais. Adicionalmente, foi observado que os desastres ocorridos catalisaram um processo de aprendizagem que culminou em políticas de barragens potencialmente melhores.

Palavras-chave: Avaliação de Políticas Ambientais. Desastres Ambientais. Barragens de Rejeito. Aprendizagem regulatória.

\section{INTRODUCTION: DISASTERS AND ENVIRONMENTAL POLICIES}

Environmental policies are imperfect and need constant monitoring and performance evaluation to support learning processes (ASSIS et al., 2012; BELLONI; SOUZA; MAGALHÃES, 2003). The improvement of environmental policies, however, does not always happen proactively. While suddenly and forcefully exposing pre-existing problems, catastrophic events often function as catalysts for change (EUROPEAN SAFETY, RELIABILITY \& DATA ASSOCIATION, 2015).

Many environmental disasters have driven the creation and improvement of environmental public policies (HOGAN, 2007; POTT; ESTRELA, 2017). In London, four years after the "Great Smog" of 1952, the Clean Air Act was created, thus establishing measures to control pollution caused by burning coal (WALLER, 1971). In 1956, in Japan, there was a significant episode of mercury contamination in the Minamata Bay that stimulated discussions on the use of chemical compounds and their effects on flora and fauna, thus leading to the ban of DDT and to an environmental movement that would gain strength in the following decade (HOGAN, 2007).

In 1977, toxic substances, including dioxin, were released due to an explosion in the chemical industry in Seveso, Italy (HOGAN, 2007). Years after this disaster, the Seveso Directive was regulated to prevent accidents involving dangerous substances and limit their adverse effects on the environment and society (POTT; ESTRELA, 2017). Still, in the late 1970s, hazardous waste disposal and human occupation in the Love Canal (USA) unfolded into reproductive problems among women and into high levels of chemical contaminants in the soil and air. This led to the approval of the Comprehensive Environmental Response, Compensation and Liability Act (Superfund), which gave the Environmental Protection Agency (EPA) the authority to respond to releases of hazardous substances that could endanger public health or the environment (ENVIRONMENTAL PROTECTION AGENCY, 2018; HOGAN, 2007).

An accident in the Three Mile Island nuclear power plant in Pennsylvania (USA) in 1979 triggered debates around the use of atomic energy. Years later, in 1986, the explosion of a nuclear reactor in Chernobyl (Ukraine) increased environmental awareness in Europe and promoted favourable conditions for the implementation of environmental policies (FREY, 2000). In the 1980s, there was also a leak of toxic gases from a pesticide industry in Bhopal (India), which resulted in the approval of the Convention 174 of the International Labor Organization (ILO), aimed at preventing industrial accidents and reducing their risks and consequences (POTT; ESTRELA, 2017).

A similar phenomenon of reactive improvement of environmental policies recently occurred in Minas Gerais, Brazil, after the failures of the Fundão tailings dam failures, in Mariana, in 2015 and of the B1 tailings dam Brumadinho in 2019. These disasters, in addition to killing hundreds of people, caused severe biophysical and socioeconomic damage. The magnitude of these damages shed light on the many flaws and limitations of existing dam safety and emergency policies (MILANEZ et al., 2019). At the state and federal levels, various legal and regulatory changes were triggered by the failures of these dams. However, the political and institutional learning of these failures remains fragmented and marginally explored in the literature.

This article sought to answer the following questions: How does the Minas Gerais state government monitor and improve its environmental policies? How did the dam failures affect the State's institutional- 
regulatory learning? More specifically, the study had a twofold objective: 1) to identify the mechanisms used by the government of Minas Gerais to improve environmental policies, and 2) to understand how the Mariana and Brumadinho disasters affected dam safety and emergency policies.

\section{POST-DISASTER POLITICAL AND INSTITUTIONAL LEARNINGS}

Catastrophic events can reveal organisational dysfunctions and stimulate reflections regarding the analysis, diagnosis and prevention capacity of the actors involved in policy-making, thus opening up opportunities for dialogue and collaborative learning between groups and organisations (EUROPEAN SAFETY, RELIABILITY \& DATA ASSOCIATION, 2015; LLORY; MONTMAYEUL, 2014). Disasters, in particular, have a considerable level of leverage to trigger change, as they attract the attention of managers, regulators and other stakeholders, generating significant pressure to investigate, understand and implement improvements, including in the regulatory system (EUROPEAN SAFETY, RELIABILITY \& DATA ASSOCIATION, 2015).

However, the post-disaster learning process is not trivial: several technical, organisational or cultural obstacles must be overcome (EUROPEAN SAFETY, RELIABILITY \& DATA ASSOCIATION, 2015). Learning involves identifying deficiencies and implementing changes at various levels of the system where different actors are involved. Through the establishment of laws, governments make priorities explicit and define limits, guiding or restricting the behaviour of public agencies and entrepreneurs. Subsequently, these laws are interpreted and regulated. To be operational, these regulations have to adapt to the particular contexts of each project, taking into account the existing resources and procedures. Finally, at the technical-operational level, legal requirements are put into practice (RASMUSSEN, 1997). In addition to these interactions, the different actors are influenced by "external pressure" during the learning process, whether political, economic or technological, as illustrated in Figure 1.

\subsection{WHEAT AND DERIVATIVES SECTOR}

The wheat and derivatives segment comprises the manufacture of wheat flour, wheat milling, the manufacture of semolina and wheat bran, the manufacture of other wheat derivatives and the manufacture of flour and mixed pasta (powder) and prepared for the manufacture of bread, cakes, cookies, etc. (ECONODATA, 2020).

According to this database, this segment consists of 798 companies distributed between 26 Brazilian states, as shown in Figure 1.

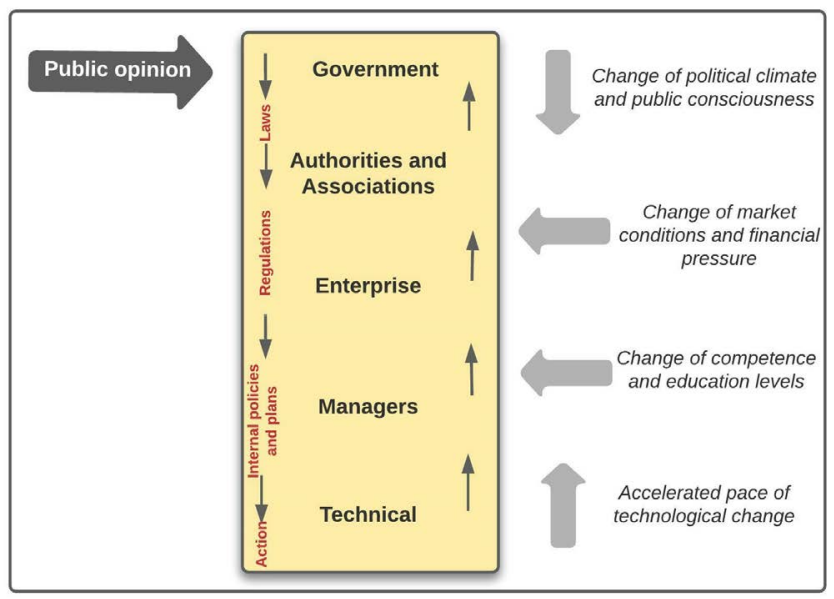

Figure 1 | Interactions between actors in the process of creating and improving policies, laws and regulations 
Post-disaster learning encompasses the steps of reporting, analysing, planning, implementing and monitoring effectiveness (EUROPEAN SAFETY, RELIABILITY \& DATA ASSOCIATION, 2015). Some organisational or cultural issues, however, may impair learning, such as the absence or poor quality of information and records; the absence of statistical and trend analysis to support decisions on future investments or organisational changes; unfamiliarity of root causes; restriction of human and financial resources; among others (EUROPEAN SAFETY, RELIABILITY \& DATA ASSOCIATION, 2015).

In many cases, political-institutional lessons learned in the post-disaster context are translated into laws and regulations. Which, by itself, does not guarantee the effectiveness of the requirements. For Barros et al. (2012), legal requirements are only efficient if they are well applied, fulfilled and assimilated by social agents. These authors further state that:

Having good laws is the first and most crucial step, but it's not enough. The standard is just a starting point. For its effectiveness, it is necessary to establish conditions that make its application feasible, such as the hiring of specialised technicians, adequate infrastructure and financial resources to carry out the work, in addition to an educated public aware of environmental issues (BARROS et al., 2012, p.173).

Furthermore, understanding the causes of a disaster, by itself, does not contribute to politicalinstitutional learning. The behavioural change of organisations, whether they are private enterprises or public bodies, the constant search for technical knowledge and the critical sense of the interested parties are some of the preponderant factors for learning from disasters. Effective actions are, therefore, crucial for learning (EUROPEAN SAFETY, RELIABILITY \& DATA ASSOCIATION, 2015).

Finally, it should be noted that limited learning leads to the recurrence of disasters. The failure of the Fundão dam in 2015 exemplifies this issue. Despite the several changes in the instruments for managing the safety and emergency plans of dams after the event, there was the second disaster in Brumadinho and an even more catastrophic one in terms of loss of human lives. This situation indicates that the analyses of the disasters were superficial, being limited to the identification of direct causes, such as technical and human flaws. Root causes, which are generally organisational, were not adequately remedied (EUROPEAN SAFETY, RELIABILITY \& DATA ASSOCIATION, 2015).

A technical study was written by Poemas (2015), published shortly after the Mariana disaster, indicated limitations in the institutional learning of the environmental agencies and dam inspectors at the state and federal levels. Such institutions were going through institutional capacity problems, such as lack of personnel, equipment and resources to promote more effective and efficient inspections. Even after the disasters, the National Mining Agency (ANM) continues to face budget restrictions and delays in the availability of resources, which hinder the proper development of planned actions (AGÊNCIA NACIONAL DE MINERAÇÃO, 2020). The failures of the tailings dams in Minas Gerais offer, therefore, a fertile ground for evaluating reactive improvements in environmental policies

\section{EVOLUTION OF TAILINGS DAM'S SAFETY AND EMERGENCY POLICIES AT THE STATE AND FEDERAL LEVELS}

The first dams designed to contain tailings from mining activities were built at the beginning of the 20th century. Previously, tailings were directly discarded into the environment, as their impacts were considered insignificant or acceptable by governments and society (ÁVILA, 2012). Tailings dams are complex structures that demand strict regulations and adequate management to reduce their many risks. In addition to the inherent hazards to the construction methods, tailings properties may change over time, and project changes may jeopardise initial safety assumptions (INTERNATIONAL COMMISSION ON LARGE DAMS, 2001). 
After the 1960s, guidelines for dam safety management were established in Brazil by creating an institution currently known as the Brazilian Dam Committee (whose acronym in Portuguese is CBDB). In the 1980s and 1990s, CBDB published books on Brazilian dams, safety procedures and guidelines for inspection, auscultation and instrumentation (MELLO; PIASENTIN, 2011).

The Federal Ministry of Mines and Energy, in the late 1980s, created a workgroup to standardise preventive and maintenance procedures aimed at dam safety. This group prepared a report dealing with monitoring and instrumentation, the frequency of inspection, general guidelines to be followed in accidents, and the definition of responsibilities for carrying out the actions (MELLO; PIASENTIN, 2011).

In 1996, CBDB drafted an Ordinance containing guidelines for assessing the safety of dams and proposing the creation of the National Dam Safety Council. However, this proposal was not pursued by the government. In 1999, CBDB prepared the Basic Guide for Dam Safety (MELLO; PIASENTIN, 2011).

In 2002, the Dam Management Program started in Minas Gerais, indicating criteria for dam classification, minimum requirements to be included in the management system, and considered in environmental studies related to the main stages of dam's licensing procedures (MINAS GERAIS, 2002).

The pioneering role of the government of Minas Gerais is primarily a result of disruptive events that occurred previously, in 1986 and 2001. During the 2000s, guidelines were therefore established in Minas Gerais to support technical security audits and the mandatory submission of the Declaration of Stability Condition (DCE) of the dams to the environmental agency.

More vital legislation on dam safety came with the sanction of Law no. 12334/2010, which established the National Policy for Dam Safety (PNSB). The bill that culminated in this law was drafted reactively after dam failures in 2001 and 2003 in Minas Gerais, reinforcing the need to approve specific legislation on this subject (ESTANISLAU; BELLEZZIA, 2017; MELLO; PIASENTIN, 2011). Furthermore, many problems were recognised, including latent vulnerabilities in projects and issues in the construction and operation of existing structures (AGÊNCIA NACIONAL DE MINERAÇÃO, 2018).

Before the PNSB, there were voluntary, isolated initiatives by some entrepreneurs who were trying to implement in their Brazilian facilities the same operational and safety standards adopted internationally in their dams (AGÊNCIA NACIONAL DE MINERAÇÃO, 2018). There was a general lack of articulation between competent authorities in the public sphere, which dealt separately with the many issues related to dams (ZONTA; TROCATE, 2016). In this sense, the PNSB was an attempt to expand government control over dams based on inspections and compilation of information, thus allowing for improved dam safety management (BRASIL, 2010).

One of PNSB's principles is that developers are legally responsible for the dam's safety, thus being required to implement actions to guarantee it, including effective management systems and compliance with the regulations. In the case of mining tailings dams, government safety inspections are the responsibility of the National Mining Agency (ANM). However, environmental agencies can carry other inspections that make up Brazil's National System of Environmental Institutions (whose acronym in Portuguese is Sisnama).

ANM, the national mining agency, established regulations for managing the safety and emergency of mining dams in 2012 and 2013. But, after the Fundão dam failure, these regulations were unified and further enhanced to incorporate the learning outcomes of this disaster (BRASIL, 2012, 2013, 2017).

After the Brumadinho disaster, a proposed bill culminated in Law 14066/2020, which changed the previous PNSB, incorporating new requirements. There were intense regulatory changes at the state and federal levels, leading to various new regulations (BRASIL, 2020). 
In Minas Gerais, after the collapse of the B1 dam, the State Policy for Dam Safety (Pesb) was established through Law no. 23291/2019, being applied to dams designed to contain and/or dispose of mining tailings, residues, water or other liquids that are associated with industrial or mining activities, being more restrictive than the PNSB (MINAS GERAIS, 2019).

The Pesb established some principles, such as the prevalence of the most protective norm for the environment and communities, as well as the prioritisation of actions of prevention, inspection and monitoring by state environmental agencies and entities. Furthermore, it determined that they should articulate with the bodies and entities responsible for the PNSB in information sharing and inspections. The requirements of the Pesb were regulated in specific normative acts, as shown in Figure 2.

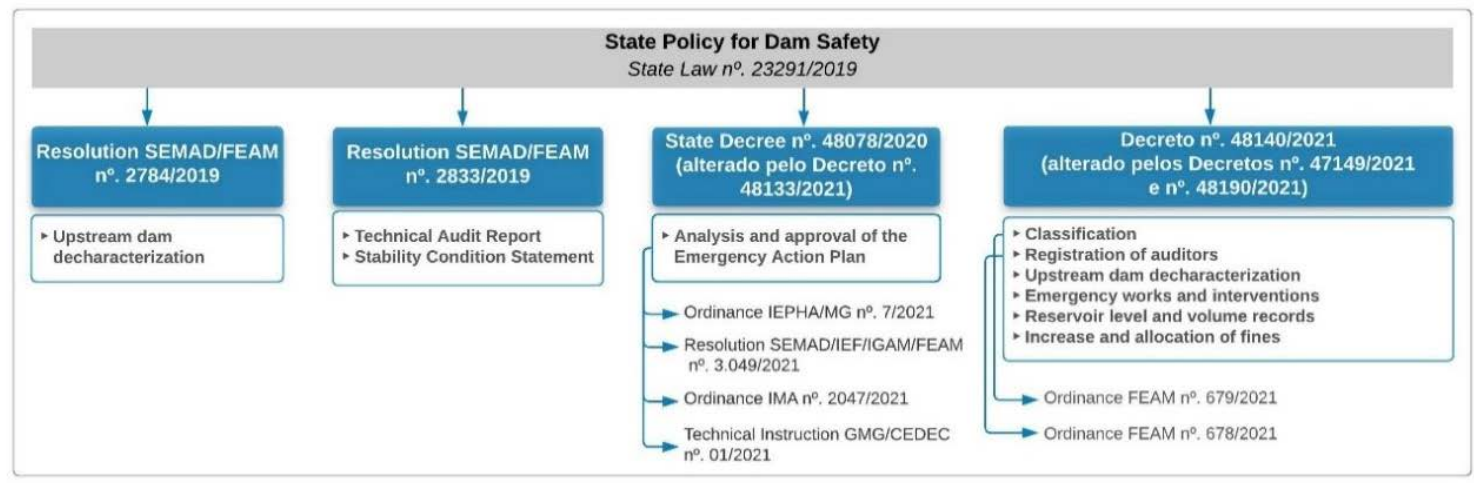

Figure 2 | State Dam Safety Policy and its Main Regulations

Source: Authors (2021)

Given the context mentioned above, this article will discuss the roles of Mariana and Brumadinho in promoting regulatory learning.

\section{METHODS}

This study addressed the particular context of Minas Gerais, which is a leading Brazilian state in mineral production with decades of experience in implementing different types of environmental policies, including policies aimed at the safety and emergency management of dams. Two qualitative data collection and analysis approaches were adopted in this research: semi-structured interviews and content analysis.

In semi-structured interviews, the researcher asks predetermined but open questions to obtain greater depth in answers. Thus, there is more control over the topics investigated than in unstructured interviews, and there is no fixed interval of responses for each question (AYRES, 2008). We opted for this methodological approach to capture deeper and contextual elements in respondents' answers.

The interviews were carried out with eight professionals who work in different departments of the State Government Environmental System (whose Portuguese acronym is Sisema). The respondents were intentionally chosen because of their knowledge and experience with other environmental policy instruments. The interviews were all telephone-based and lasted an average of $\mathbf{4 5}$ minutes (between 30 and 60 minutes). They were recorded using a smartphone application and later transcribed and analysed. All respondents were aware of the purpose of the study and signed an Informed Consent Form previously approved by the Research Ethics Committee of the Federal University of Ouro Preto. The participants were coded to preserve their identities (P1 to P8). Table 1 presents the details of the methodology used in the interviews. 
Table 1 | Methodology used in semi-structured interviews

\begin{tabular}{|c|c|}
\hline Number of respondents & Eight (identified as $P 1$ to $P 8$ ) \\
\hline Date of the interviews & January/2019, February/2019 and March/2020 \\
\hline Respondents' profile & $\begin{array}{c}\text { Managers and analysts from the State Secretary for the Environment and Sustainable } \\
\text { Development (Semad), State Forest Institute (IEF), Institute for Water Management } \\
\text { (Igam) and State Environment Foundation (Feam), responsible for the implementation } \\
\text { and control of environmental policy instruments }\end{array}$ \\
\hline Main interview content & $\begin{array}{l}\text { Respondent's profile and experience, performance controls (administrative and } \\
\text { territorial), challenges and priorities in improving environmental policy instruments }\end{array}$ \\
\hline Types of questions & Open \\
\hline Questionnaire type & Semi-structured \\
\hline Communication media & Phone calls (recorded through smartphone app) \\
\hline Data analysis & Transcription, coding, and analysis of patterns and relevant content \\
\hline
\end{tabular}

Source: : Authors (2021)

Through interviews, we sought to investigate the study's first objective, namely, how the state government monitors and evaluates the performance of environmental policies. More specifically, the following themes were explored: which technologies, tools or indicators are used, the main challenges faced, and the perception of professionals about the effectiveness of environmental policies in the state. In the context of this research, effectiveness is understood as the achievement of the objective proposed by a policy, be it the change or maintenance of specific environmental conditions. The primary purpose of the interviews was to obtain a general overview of policy learning and control at the state government. Specificities of one or another environmental policy instrument were not further explored.

The content analysis of policies, laws and regulations related to dam safety and emergency management required careful evaluations of textual material (KRIPPENDORFF, 2004). This method included categorising qualitative textual data into groups of similar entities to identify consistent patterns and relationships between variables or themes (JULIEN, 2008). This method proved to be suitable for analysing the temporal evolution of legal instruments aimed at tailings dams.

This study evaluated the primary laws and regulations enacted until 31 May 2021 at the state level, in Minas Gerais, and at the federal level. A matrix was used to organise the legal and regulatory changes that took place after the failures. Based on the identified changes, we discuss the learning process triggered by the disasters

\section{RESULTS AND DISCUSSIONS}

\subsection{EVALUATION OF THE PERFORMANCE AND EFFECTIVENESS OF ENVIRONMENTAL POLICIES IN MINAS GERAIS}

The interviewees pointed out a series of issues that hinder or prevent the control of the performance of environmental policies in Minas Gerais: the lack of systematic monitoring of the improvement of environmental quality; the absence of constant monitoring of environmental data; incompatible systems, which are restricted to administrative controls and even the inexistence of methods, among others, were reported. 
Participant P1, who held several managerial positions related to protected areas and conservation policies, stated that "there are some tools that we use that bring some indicators, but they are of little significance [...] there is no such systematic monitoring in connection with the environmental quality of the territory". Participant P2, who has extensive managerial experience in inspection and administrative sanctions, reported that he uses a basic system that cannot verify the instrument's effectiveness in terms of environmental quality outcomes.

Respondents cited the importance of using systems to manage environmental policy instruments and control their performance. However, several problems were reported in the existing systems, such as low reliability, modernisation, and customisation. Interviewee P6, who worked in the management of water resources and sustainable development policies, stated: "[...] today our database is very inconsistent because the old system did not have control over the consistency of the data released by the analysts". The inspection mentioned above and sanctions manager, P2, reported that "[...] the system does have some condition to generate some reports, but we do not use it daily". And he added: "we need a better system, that's for sure [...] there's even a reliability problem in it too."

The precarious systematisation and availability of data reported by the research participants is not a recent issue in environmental agencies in Minas Gerais. Ribeiro (2005) detected in his study that, in many cases, data were available in these institutions. Still, they were not presented in an organised and systematic way, demanding further collection and reporting. This situation was also observed by Assis et al. (2012) in an analysis of Brazilian environmental policies.

The scarcity of information about the performance of environmental policies coordinated by the state government makes it difficult for public agencies to implement and improve policies, as well as prioritise efforts, leading to institutional disparities: while some instruments have staff and resources for its execution, others receive little attention and are underutilised.

Regarding the effectiveness of environmental policy instruments, there were different perceptions among interviewees. This was already expected since other devices have different characteristics, effects, levels of regulation and institutional maturity. It was reported by participant P4, who has extensive experience in forest and vegetation removal approvals and management, that when there is a tangle of norms related to a particular environmental policy instrument, it adds complexity, making it impractical to manage effectiveness.

Participants P2, P3, P5 and P7 were of the general opinion that the state environmental policies are effective, arguing that they contribute to the control of pollution and environmental degradation, act as barriers to the irregular occupation of natural areas or promote environmental awareness using penalties and sanctions. In other words, they see effectiveness in the mere existence of environmental policies. This perception that the absence of policies would aggravate environmental quality corroborates the view of Moura (2016), who stated:

[...] there is a perception that many environmental problems have been worsening in the country, while the instruments devised for environmental policy have not advanced - at a sufficient pace and intensity - in the changes necessary for better management of the environment. Even so, there is no doubt that the deterioration of environmental quality in this period would have been more serious if these regulatory, economic, voluntary or informational tools had not been used to address environmental problems (MOURA, 2016, p. $139-140$ ).

However, it is noteworthy that "contributing to a goal" and "achieving a goal" are different issues, as assumed in the concept of effectiveness. The limitation of human resources, low investments in the technical qualification of the teams, insufficiency or poor distribution of financial resources, decisions distorted by political influences, lack of articulation between environmental agencies, lack of clear priorities and a focus on document analysis to the detriment of inspection were pointed out by the 
several interviewees as the main bottlenecks for the effectiveness of environmental policy instruments. For example, participants P1, P2 and P3 externalised during the interviews that:

(it is not effective) due to lack of resources and resources include people and financial resources as well. So, there is a lack of money, and we waste a lot of time trying to resolve things and, in the end, we always come up against some government decision, lack of resources, a new year, a state bureaucracy $[\ldots](\mathrm{P} 1)$.

[...] the environment demands many different focuses, there is licensing, there is inspection, so we stay in a 'pot' [sic], waiting for many other priorities to be met (P2).

[...] the money is used for many other things, except for its core activity, for its effective purpose [...] the money that is collected is not applied as it should be (P3).

For Moura (2016), institutional structures and participation processes involving social and economic agents determine the quality of environmental policies. For this author, the population's involvement in the elaboration, execution and evaluation of policies is one of the pillars of success. In this regard, the interviewees mentioned that public participation in environmental policies occurs through consultations, meetings, hearings, technical chambers and councils. Participatory management was mentioned in the interviews as an essential step towards the effectiveness of the instruments, which corroborates Assis et al. (2012, p.18), who stated: "It is essential that different actors, who may have conflicting visions and objectives, be incorporated into the assessment".

Despite the recognition of the importance of civil society participation in the formulation of effective environmental public policies, there are structural issues in Minas Gerais that lead to the pseudosocial involvement in public hearings and State Council for Environmental Policy (Copam) chambers (CARNEIRO, 2005; MOURA, 2016; SALHEB et al., 2009).

The interviews demonstrated weak preparation and articulation among state environmental agencies when evaluating the performance of policies, thus reinforcing the obscure "cause-and-effect relationship" between policies and environmental quality on the ground. The lack of priorities and evidence of effectiveness hinders the improvement of policies, as several relevant aspects, such as the management capacity of environmental agencies and entities, are not considered in decision-making. Difficulties and challenges in evaluating the performance of environmental policies pointed out by the interviewees were also identified in the literature.

It was observed that in Minas Gerais, difficulties in measuring progress in environmental policies result from a lack of structured assessment mechanisms. For Moura (2016), without these mechanisms, notions of effectiveness will remain imprecise or partial.

The existence of a continuous learning system was not evidenced in the interviews. This situation hinders the preventive action of the State. The occurrence of disasters in Minas Gerais is likely a symptom of the inefficiency of the policy control. Unwanted events become catalysts for a learning process that reactively seeks improvements based on the causes and consequences of what happened.

However, the difficulties presented by the interviewees cannot represent an impediment to the performance evaluation of environmental policies. They must reinforce the search for knowledge and investments so that the evaluation is helpful to direct policies, promoting improvements and the efficient allocation of public resources based on participatory and democratic mechanisms. 


\subsection{POST-DISASTER LEARNING IN MINAS GERAIS: ANALYSIS OF LEGISLATIVE CHANGES ON DAM SAFETY AND EMERGENCY MANAGEMENT}

The second part of this study focused more specifically on policy changes aimed at dam safety and emergency management, which reflect a reaction to the Mariana and Brumadinho disasters. This part sought to understand the details of the changes and the 'bulk' of the lessons learned. This part, however, was not based on interviews but, as previously explained in the methods section, on content analysis of laws and regulations. As shown in Table 2, an intense legislative and regulatory activity was identified after the Mariana disaster and, above all, after the Brumadinho disaster.

Table 2 | Laws and regulations aimed at the safety and emergency management of tailings dams

\section{STATE LEGISLATION}

Mariana's pre-disaster

\begin{tabular}{|c|c|}
\hline Resolution Semad no. 99/2002 & January 29, 2002 \\
\hline Normative Deliberation Copam no. 62/2002 & December 17, 2002 \\
\hline Normative Deliberation Copam no. 74/2004 & September 9, 2004 \\
\hline Normative Deliberation Copam no. 87/2005 & June 17, 2005 \\
\hline Normative Deliberation Copam no. 124/2008 & October 9, 2008 \\
\hline State Decree n‥ 44.844/2008 & June 25, 2008 \\
\hline \multicolumn{2}{|c|}{ Mariana's post-disaster } \\
\hline State Decree $n^{\circ} .46 .892 / 2015$ & November 20, 2015 \\
\hline State Law no. 21.972/2016 & January 21, 2016 \\
\hline State Decree ${ }^{\circ} .46 .993 / 2016$ & May 2, 2016 \\
\hline Normative Deliberation Copam no. 210/2016 & September 21, 2016 \\
\hline Normative Deliberation Copam no. 217/2017 & December 06, 2017 \\
\hline Normative Deliberation Copam no. 228/2018 & November 28, 2018 \\
\hline \multicolumn{2}{|c|}{ Brumadinho's post-disaster } \\
\hline Resolution Semad n‥ 2.762/2019 & January 29, 2019 \\
\hline Resolution Semad/Feam no. 2.765/2019 & January 30, 2019 \\
\hline State Law no. 23.291/2019 & February 25, 2019 \\
\hline Resolution Semad/Feam no. 2.784/2019 & March 21, 2019 \\
\hline Official Notice GMG/Cedec no. 02/2019 & June 25, 2019 \\
\hline Resolution Semad/Feam no. 2.833/2019 & August 26, 2019 \\
\hline State Decree n‥ 47.739/2019 & October 18, 2019 \\
\hline State Decree n‥ 48.078/2020 & November 5, 2020 \\
\hline State Decree n‥ 48.140/2021 & February 25, 2021 \\
\hline Resolution Semad/Feam/IEF/Igam no. 3.049/2021 & March 2, 2021 \\
\hline Ordinance IMA n‥ 2047/2021 & March 31, 2021 \\
\hline Ordinance lepha/MG no. 7/2021 & April 9, 2021 \\
\hline Ordinance Feam no. 678/2021 & May 6, 2021 \\
\hline Ordinance Feam no. 679/2021 & May 6, 2021 \\
\hline Technical Instruction GMG/Cedec no. 01/2021 & May 21, 2021 \\
\hline
\end{tabular}




\begin{tabular}{|c|c|}
\hline Federal Law no. 12.334/2010 & September 20, 2010 \\
\hline Ordinance DNPM n‥ 416/2012 & September 03, 2012 \\
\hline Ordinance DNPM n‥ 526/2013 & December 09, 2013 \\
\hline \multicolumn{2}{|l|}{ Mariana's post-disaster } \\
\hline Ordinance DNPM n․ 14/2016 & January 15, 2016 \\
\hline Ordinance Secretaria Nacional de Proteção e Defesa Civil no. 187/2016 & October 26, 2016 \\
\hline Ordinance DNPM n‥ 70.389/2017 & May 17, 2017 \\
\hline \multicolumn{2}{|l|}{ Brumadinho's post-disaster } \\
\hline $\begin{array}{l}\text { Resolution of the Ministerial Council for the Oversight of Disaster Responses no. } \\
\qquad 1 / 2019\end{array}$ & January 28, 2019 \\
\hline $\begin{array}{l}\text { Resolution of the Ministerial Council for the Oversight of Disaster Responses no. } \\
\qquad 2 / 2019\end{array}$ & January 28, 2019 \\
\hline Resolution ANM n. 4/2019 & February 15, 2019 \\
\hline Resolution ANM n. 13/2019 & August 8, 2019 \\
\hline Resolution ANM n³2/2020 & May 11, 2020 \\
\hline Resolution ANM n 40/2020 & July 6, 2020 \\
\hline Federal Law no. 14.066/2020 & September 30, 2020 \\
\hline Resolution ANM n․ 51/2020 & December 24, 2020 \\
\hline Resolution ANM n․ 56/2021 & January 28, 2021 \\
\hline
\end{tabular}

Source: : Authors (2021)

The study identified that there was, particularly in Minas Gerais, an incremental learning process. Years before the publication of the PNSB, the State already had a dam classification system and required documents and data on the dam structures during the environmental licensing process. The state government was the precursor of several changes, later implemented at the federal level for mining dams and other dams. Table 3 exemplifies the pioneering role of Minas Gerais.

Table 3 | Examples of pioneering dam safety regulations in Minas Gerais

\begin{tabular}{|c|c|c|}
\hline Description & State Level & $\begin{array}{c}\text { Federal Level } \\
\text { (Mining dams and/or other types) }\end{array}$ \\
\hline Dam Registration & $\begin{array}{l}\text { Resolution Semad no. } \\
\text { 99/2002 }\end{array}$ & Federal Law no. 12.334/2010 \\
\hline $\begin{array}{l}\text { Determines the registration of professionals who } \\
\text { attest to the stability of dams }\end{array}$ & State Law no. 23.291/2019 & Federal Law no. 14.066/2020 \\
\hline $\begin{array}{l}\text { Determines measures to rescue people, animals and } \\
\text { cultural heritage, mitigate environmental impacts } \\
\text { and ensure water supply }\end{array}$ & State Law no. 23.291/2019 & Federal Law no. 14.066/2020 \\
\hline $\begin{array}{l}\text { Determines upstream dam 'de-characterization' } \\
\text { (decommissioning) }\end{array}$ & $\begin{array}{l}\text { Resolution Semad/Feam } \\
n^{\circ} 2.765 / 2019\end{array}$ & Resolution ANM no. 4/2019 \\
\hline $\begin{array}{c}\text { Determines the analysis and approval of Emergency } \\
\text { Action Plana }\end{array}$ & $\begin{array}{l}\text { State Decree } n \cong . \\
48.078 / 2020\end{array}$ & Resolution ANM no. 51/2020 \\
\hline $\begin{array}{l}\text { Establishes guidelines for the elaboration of flood } \\
\text { studies }\end{array}$ & $\begin{array}{l}\text { Official Notice GMG/ } \\
\text { Cedec no. 02/2019 }\end{array}$ & Resolution ANM no. 32/2020 \\
\hline $\begin{array}{c}\text { Determines public hearings to present the } \\
\text { Emergency Action Plan }\end{array}$ & State Law no. 23.291/2019 & Federal Law no. 14.066/2020 \\
\hline
\end{tabular}


It was found that some learnings catalysed by the failure of the Fundão dam were materialised only after the collapse of the B1 dam. An example is the implementation of the State Policy for Dam Safety (Pesb), which resulted from the Popular Initiative Law Project called "Sea of Mud Never Again", proposed in July 2016. After the collapse of the B1 dam, the urgency and relevance of the law mentioned above was more clearly perceived, thus leading to its sanction one month after the dam break.

Therefore, it was "necessary" the occurrence of two disasters for the implementation of some determinations at the state level, such as: detailing of flood studies' methodology, mandatory threephase environmental licensing for dam construction and change, the requirement of a guarantee to ensure socio-environmental recovery, public hearings to discuss the conceptual design of dams, environmental licenses conditioned to the approval of Emergency Action Plans (by various sector entities), requirement for the prioritisation of disposal alternatives that minimise social and environmental risks and promote the dewatering of tailings and residues, creation of Dam Management Information System (Sigibar) and compatibility of the state and federal dam classification systems.

At the federal level, the ANM, mainly after the failure of the B1 dam, established new requirements related to dam safety and emergency management. Furthermore, a cooperation agreement was signed with the Organization for Economic Cooperation and Development (OECD) to review the regulation and governance of the mineral sector. The ANM aims to identify regulatory barriers that may hinder the implementation of public policies and correct inefficiencies in the mineral sector based on the best global practices from countries such as Canada, Australia and the United States (AGÊNCIA NACIONAL DE MINERAÇÃO, 2020). In its preliminary report, the OECD highlighted the need to optimise inspection activities, to reduce the risks of accidents (AGÊNCIA NACIONAL DE MINERAÇÃO, 2021).

A large part of the effort of public and private institutions has been focused on improving emergency management by dealing with procedures that can avoid failures or minimise damage resulting from them, especially loss of life. It is worth mentioning that, in response to the Brumadinho disaster, the Global Industry Standard on Tailings Management was established, which, based on the lessons learned from recent failures and existing good practices, set out global guidelines for the safe management of dams (UNITED NATIONS ENVIRONMENT PROGRAMME; INTERNATIONAL COUNCIL ON MINING AND METALS; PRINCIPLES FOR RESPONSIBLE INVESTMENT, 2020). While the mining industry's interests prevailed in its preparation, this Standard defined auditable principles and requirements that emphasise the relevance of engagement and communication with stakeholders throughout the entire life cycle of dams (HOPKINS; KEMP, 2021).

The analysis carried out here suggests that changes in legal requirements are not enough to prevent new disasters. It is necessary that developers comply with legal requirements and that the supervisory and regulatory bodies have sufficient financial and human resources to monitor compliance with their determinations. If laws and regulations disregard the capacity of supervisory bodies or licensing entities, the effectiveness of existing policies is compromised. Regulatory changes in the context of developing economies like Brazil must be accompanied by capacity-building and intuitional strengthening.

\section{FINAL REMARKS}

The proactive performance assessment of environmental policies enables a better understanding of policies' actual implications and opportunities for improvement, thus legitimising political changes and helping governments to make more scientific and evidence-based decisions, which can, ultimately, contribute to the enhanced distribution and use of resources (ASSIS et al., 2012; BELLONI; SOUZA; MAGALHÃES, 2003; CRABBE; LEROY, 2008; MICKWITZ, 2006).

In Brazil, however, the socio-environmental effects of policies are not constantly monitored, making their assessment and, consequently, political-institutional learning difficult. Specifically, in Minas Gerais, 
interviewees suggested that state environmental agencies still have weak control and articulation in assessing policies. Environmental disasters become a 'natural' catalyst of policy improvement in this context, as reflected in tailings dams' recent legislative and regulatory changes.

The failures of the Fundão and B1 dams stimulated discussions about the effectiveness of dam safety and emergency policies, and therefore accelerated a learning process. Regrettably, however, the Fundão disaster was not enough. It was "necessary" for the second disaster of Brumadinho to simulate more meaningful learning (MILANEZ, 2021).

This article identified several institutional challenges faced by the government of Minas Gerais that hinder or prevent the control of environmental policies and, consequently, the prioritisation of correction and preventive measures. In the present study, empirical evidence was obtained about the capacity of public institutions, and it was found that the perception of professionals working in state environmental agencies corroborates previous studies.

When it comes to dam safety and emergency management, the assessment carried out revealed that the changes that took place were not mere coincidences: the vast majority of, if not all, regulatory changes are directly related to the causes or consequences of both disasters. Advances in dam safety could occur due to studies, methodologies and good practices disseminated among professionals, but not in the speed and intensity observed here.

The identified challenges of policy effectiveness evaluations are mainly related to mismatches between laws' intended objectives and their actual implementation, budget cuts, lack of personnel and technical resources, and lack of knowledge or disregard for the benefits of policies at different levels of management. It is, therefore necessary, among other aspects, to strengthen the institutional capacity of government agencies.

Mariana and Brumadinho demonstrated no "zero risk" for tailings dams, no matter how good the engineering projects and legal requirements safeguard these structures. Developers must comply with legal requirements, and the supervisory and regulatory bodies need sufficient human and financial resources to monitor compliance with their determinations.

\section{ACKNOWLEDGEMENTS}

The authors would like to thank the Coordination for the Improvement of Higher Education Personnel (Capes) for the Masters' scholarship, and the National Council for Scientific and Technological Development (CNPq) for the research scholarship 132558/ 2018-1, as well as for the financial support to the project $311201 / 2018-0$.

\section{REFERENCES}

AGÊNCIA NACIONAL DE MINERAÇÃO. Manual de Fiscalização de Barragens de Mineração. 2018. Brasília.

AGÊNCIA NACIONAL DE MINERAÇÃO. Relatório de Gestão da Agência Nacional de Mineração (ANM). Brasília, 2020. Available at: https://www.gov.br/anm/pt-br/acesso-a-informacao/acoes-e-programas/relatorio-gestao/ relatorio-de-gestao-2013-exercicio-2019. Accessed in: 5 jun. 2020.

AGÊNCIA NACIONAL DE MINERAÇÃO. OCDE mostra caminho para a modernização do setor de mineração. 2021. Available at: https://www.gov.br/anm/pt-br/assuntos/noticias/ocde-mostra-caminho-para-modernizacao-dosetor-de-mineracao. Accessed in: 16 maio 2021.

ASSIS, M. P. et al. Avaliação de políticas ambientais: desafios e perspectivas. Saúde e Sociedade, v. 21, n. 3, p. 7-20, 2012. 
ÁVILA, J. P. Barragens de Rejeitos no Brasil. Rio de Janeiro. Comitê Brasileiro de Barragens, 2012.

AYRES, L. Semi-Structure Interview. In: GIVEN, L. M. (Ed.). The Sage Encyclopedia of Qualitative Research Methods, v. 1 \& 2, p. 810-811. Thousand Oaks: Sage Publications, 2008.

BARROS, D. A. et al. Breve análise dos instrumentos da política de gestão ambiental brasileira. Política \& Sociedade, v. 11, n. 22, p. 155-179, 2012.

BELLONI, I.; SOUZA, L. C.; MAGALHÃES, H. Metodologia de avaliação em políticas públicas: uma experiência em educação profissional. 3. ed. São Paulo: Cortez, 2003.

BRASIL. Lei $n^{\circ}$ 12.334, de 20 de setembro de 2010. Estabelece a Política Nacional de Segurança de Barragens destinadas à acumulação de água para quaisquer usos, à disposição final ou temporária de rejeitos e à acumulação de resíduos industriais. Brasília, 2010.

BRASIL. Portaria n 416, de 03 de setembro de 2012. Cria o Cadastro Nacional de Barragens de Mineração e dispõe sobre o Plano de Segurança, Revisão Periódica de Segurança e Inspeções Regulares e Especiais de Segurança das Barragens de Mineração. Brasília, 2012.

BRASIL. Portaria n $^{\circ}$ 526, de 09 de dezembro de 2013. Estabelece a periodicidade de atualização e revisão, a qualificação do responsável técnico, o conteúdo mínimo e o nível de detalhamento do Plano de Ação de Emergência das Barragens de Mineração (PAEBM). Brasília, 2013.

BRASIL. Portaria n 70.389, de 17 de maio de 2017. Cria o Cadastro Nacional de Barragens de Mineração, o Sistema Integrado de Gestão em Segurança de Barragens de Mineração e estabelece a periodicidade de execução ou atualização, e a qualificação dos responsáveis técnicos. Brasília, 2017.

BRASIL. Lei $n^{\circ}$ 14.066, de 30 de setembro de 2020. Altera a Lei $n^{\circ} 12.334$, de 20 de setembro de 2010, que estabelece a Política Nacional de Segurança de Barragens (PNSB) e outras. Brasília, 2020.

CARNEIRO, E. J. A oligarquização da "política ambiental" mineira. A insustentável leveza da política ambiental: desenvolvimento e conflitos socioambientais. Belo Horizonte, 2005.

CRABBÉ, A.; LEROY, P. The Handbook of Environmental Policy Evaluation. London: Earthscan, 2008.

DENSCOMBE, M. The Good Research Guide: for small-scale social research projects. New York Open University Press, 2007.

ENVIRONMENTAL PROTECTION AGENCY. What is Superfund? Available at: https://www.epa.gov/superfund/ what-superfund. Accessed in: 11 maio 2021.

ESTANISLAU, F. N.; BELLEZZIA, V. DO C. Segurança de Barragens: bases legais de um cuidado razoável. Brasília, 2017. Available at: http://conpedi.danilolr.info/publicacoes/roj0xn13/5n13472j/ZPJ95gUA9VB375u7.pdf. Accessed in: 16 maio 2021.

EUROPEAN SAFETY, RELIABILITY \& DATA ASSOCIATION. Barriers to learning from incidents and accidents. Available at: https://www.esreda.org/wp-content/uploads/2021/01/ESReDA-barriers-learning-accidents-1.pdf. Accessed in: 10 jan. 2021.

FREY, K. Políticas Públicas: um debate conceitual e reflexões referentes à prática da análise de políticas públicas no Brasil. Planejamento e Políticas Públicas, n. 21, 2000.

HOGAN, D. J. Dinâmica populacional e mudança ambiental: cenários para o desenvolvimento brasileiro. Campinas: Núcleo de Estudos de População-Nepo/Unicamp, 2007.

HOPKINS, A.; KEMP, D. Credibility Crisis: Brumadinho and the Politics of Mining Industry Reform, 2021.

INTERNATIONAL COMMISSION ON LARGE DAMS. Tailings dams risk of dangerous occurrences. Paris, 2001. Available at: https://ussdams.wildapricot.org/resources/Documents/ICOLD>2001Bulletin121.pdf. Accessed in: 2 out. 2020. 
JULIEN, H. Content Analysis. In: GIVEN, L. M. (Ed.). The Sage Encyclopedia of Qualitative Research Methods, v. 1 \& 2, p. 120-122. Thousand Oaks: Sage Publications, 2008.

KRIPPENDORFF, K. Content analysis: an introduction to its methodology. Thousand Oaks: Sage Publications, 2004.

LLORY, M.; MONTMAYEUL, R. O acidente e a organização. Belo Horizonte: Fabrefactum, 2014.

MELLO, F. M.; PIASENTIN, C. A história das Barragens no Brasil, séculos XIX, XX e XXI: cinquenta anos do Comitê Brasileiro de Barragens. Rio de Janeiro: CBDB, 2011.

MICKWITZ, P. Environmental Policy Evaluation: concepts ans practice. Saarijärvi: Finnish Society of Sciences and Letters, 2006.

MILANEZ, B. et al. Minas não há mais: avaliação dos aspectos econômicos e institucionais do desastre da Vale na Bacia do Rio Paraopeba. Versos - Textos para Discussão. PoEMAS, 2019.

MILANEZ, B. Mapping industrial disaster recovery: lessons from mining dam failures in Brazil. The Extractive Industries and Society, v. 8, Issue 2, June 2021.

MINAS GERAIS. Deliberação Normativa Copam $n^{\circ}$ 62, de 17 de dezembro de 2002. Dispõe sobre critérios de classificação de barragens de contenção de rejeitos, de resíduos e de reservatório de água em empreendimentos industriais e de mineração no Estado de Minas Gerais. Belo Horizonte, 2002.

MINAS GERAIS. Lei 23.291, de 25 de fevereiro de 2019. Institui a política estadual de segurança de barragens. Belo Horizonte, 2019.

MOURA, A. M. M. DE. Governança Ambiental no Brasil: instituições, atores e políticas públicas. Brasília: Instituto de Pesquisa Econômica Aplicada, 2016.

POEMAS. Antes fosse mais leve a carga: avaliação dos aspectos econômicos, políticos e sociais do desastre da Samarco/Vale/BHP em Mariana (MG). Mimeo. 2015.

POTT, C. M.; ESTRELA, C. C. Histórico ambiental: desastres ambientais e o despertar de um novo pensamento. Estudos Avançados, v. 31, n. 89, p. 271-283, 2017.

RASMUSSEN, J. Risk Management in a dynamic society: a modelling problem. Safety Science, v. 27, n. 2, p. 183213, 1997.

RIBEIRO, J. C. J. Desenvolvimento de modelo para avaliação de desempenho de política pública de meio ambiente - estudo de caso: Estado de Minas Gerais. 2005. Tese (Doutorado em Saneamento, Meio Ambiente e Recursos Hídricos) - Universidade Federal de Minas Gerais, Belo Horizonte.

SALHEB, G. J. M. et al. Políticas públicas e meio ambiente: reflexões preliminares. Revista Internacional de Direito Ambiental e Políticas Públicas, v. 1, n. 1, p. 5-27, 2009.

UNITED NATIONS ENVIRONMENT PROGRAMME. International Council on Mining and Metals. Principles for Responsible Investment. Padrão Global da Indústria para Gestão de Rejeitos, 2020. Available at: https://ibram. org.br/wp-content/uploads/2020/08/global-tailings-standard_PT.pdf. Accessed in: 1 maio 2021.

WALLER, R. E. Air Pollution and Community Health. London, 1971.

ZONTA, M.; TROCATE, C. A questão mineral no Brasil. Antes fosse mais leve a carga: reflexões sobre o desastre da Samarco/Vale/BHP Billiton. Marabá: Editorial iGuana, 2016. v. 2. 